\title{
Evaluation of Results of Closed Reamed Nailing for Diaphyseal Fracture of the Tibia-Experience of 35 cases
}

\author{
Md. Habibul Hasan, ${ }^{1}$ Mohd. Alamgir Hossain, ${ }^{2}$ Md. Enamul Haque, ${ }^{3}$ \\ Md. Ahsanuzaman, ${ }^{4}$ Elora parveen, ${ }^{5}$ Abul Kalam Azad ${ }^{6}$
}

\begin{abstract}
Introduction: Tibia is a subcutaneous bone and is more prone to trauma. Different treatment modalities exist for fracture shaft of the tibia. Intramedullary nailing in the treatment of fractures of the long bones was technically developed and popularized by Küntscher in the 1940's. Treatment of tibial fracture in adult is a challenge to orthopedic surgeons due to poor soft tissue coverage and blood supply.
\end{abstract}

Materials and methods: This study was prospective and interventional. This study was carried out in the private hospitals in Rajshahi over a period of 3 years. Total 35 patients with tibial shaft fracture were studied. Inclusion criteria were displaced closed diaphyseal fracture shaft of the Tibia, open fracture with Gustillo 1, 2 and 3A attended within 24 hours. Exclusion criteria were patient's age below 16 years, grossly lacerated fracture, undisplaced fracture, patient unwilling to operate. Thirty three cases were operated within one week only two cases operated at 2 months due to angulations following conservative treatment. Open fracture was fixed within 2448 hours. Broad spectrum antibiotic injectable Moxifloxacin was used in most of the cases for 2 doses then oral, Injectable Meropenem was used for the open fracture. Those patients suffering from G-3A fracture wound were covered by Hemisoleal flap Two weeks after primary surgery and were uneventful. In most of the cases image intensification was not used only three cases needed image intensification in case the fractures in lower $1 / 4$ th of the shaft to see the end of the Nail.

Results: Two patients developed postoperative superficial wound infection which was recovered by regular dressing. Only one patient needed post-operative cast support because the fracture was comminuted. All patients started Knee bending from first post-operative day. Full range of knee movement was found in all patients. All fracture united properly within 12 weeks to 22 weeks with mean of 17 weeks. No cases of implant failure detected during the study period.

Conclusion: The results of the current study reveal that the reamed interlocking nail in treatment of tibial diaphyseal fracture is safe, easy, successful and preferable method may be recommended as a stable fixation with early return to daily activities.

Key words: diaphyseal fracture tibia, closed reduction, intramedullary nail fixation.

TAJ 2019; 32: No-1: 09-16

1 Junior Consultant, Department of Orthopaedic Surgery Rajshahi Medical College Hospital.

${ }^{2}$ Assistant Professor, Department of Orthopaedic Surgery, Rajshahi Medical College.

${ }^{3}$ Assistant Professor, Department of Orthopaedic Surgery, Rajshahi Medical College.

${ }^{4}$ Registrar, Department of Orthopaedic Surgery, Rajshahi Medical College Hospital.

${ }^{5}$ Resident, Department of Medicine, Rajshahi Medical College Hospital.

${ }^{6}$ Assistant Professor, Department of Anaesthesiology, Rajshahi Medical College. 


\section{Introduction}

Tibia and fibula have the highest incidence of the diaphyseal fractures of the long bones. ${ }^{1}$ The subcutaneous nature of the medial border as well as the delicate blood supply increases the vulnerability to open injuries, deep infection, malunion and non-union. ${ }^{2}$ Moreover compartment syndrome, neuro-vascular injury and infection might add to this burden. Fractures of the shaft of tibia cannot be treated by following a simple set of rules. Because of its location tibia is exposed to frequent injury. ${ }^{3}$ Tibial fractures can be treated nonoperatively as well as operatively. Fractures in which closed treatment is inappropriate can be treated with plate and screw fixation, intramedullay fixation and external fixation. ${ }^{3}$

In the past, tibial shaft fracture were managed by immobilization in a plaster cast. ${ }^{4}$

Thereafter functional brace has been used commonly The plating resulted in higher incidence of non-union, infection and fixation failure.$^{6} 1960$ s and 1970s external fixation was most popular. ${ }^{7}$ The external fixation resulted in Pin tract infection and sometimes osteomyelitis of bone. ${ }^{8}$

Intramedullary nailing is indicated for the majority of closed Mid shaft fractures of the tibia as well as for open fractures with adequate soft tissue cover. ${ }^{9}$ Intramedullary nail (Lottes, Ender) has been used for a long time for fixation of tibia. ${ }^{10}$ The first use of an intramedullary rod is attributed by lambott in 1907. $^{11}$ In 1974 a semi-rigid triflange intramedullary nail is introduced for closed nailing in tibia without reaming. ${ }^{12}$ Since the late 1950's open reduction and internal fixation (ORIF) was reserved for situations in which an adequate reduction could not be obtained by conservative means. ${ }^{13}$ ORIF often necessitates extensive dissection and tissue devitalization, creating an environment less favorable for fracture union and more prone to bone infection. ${ }^{13}$ Invention of interlocking systems especially closed technique has revolutionized the management of fractures of the tibia. ${ }^{14}$ It has eliminated most of the problems and complications associated with conservative methods and plating and made possible to stabilize even most difficult, segmental, severely comminuted and junctional fractures without jeopardizing its blood supply. These days interlocking nailing system uses the principle of closed technique of Alignment with superadded advantage of immobilization and stabilization with locking bolts without need of any external support (cast).$^{15}$ Intramedullary nailing of the tibia greatly improves rotational stability. This procedure reduces hospital stay, provides early mobilization and better outcome anatomically as well as functionally. ${ }^{16}$

The treatment of open tibial fractures is difficult and often controversial with no general consensus on their management. ${ }^{17}$ The management of open fractures is regarded as an orthopaedic emergency. ${ }^{18}$ The traditional method of treating open tibial fractures was with an external fixator preferably within six hours of injury. ${ }^{19,20}$ Monolateral external fixation has been employed to treat open tibial fractures with great success; however, not without significant complications. $^{21,22}$ With the improvement in antibiotic use and surgical technique, the use of intramedullary nails has evolved from low energy open Gustilo grade 1 and grade 2 fractures to more severe Gustilo grade 3 injuries, with excellent long-term results. ${ }^{23,24}$

Both reamed andunreamed nails have become the accepted standard of care in many institutions ensuring axial Alignment, Early weight bearing, bony union and early return to pre-injury function with minimal complications..$^{25-27}$ The use of locked intramedullary nailing of closed and grade 1 and 2 open fracture is a safe techniques, it combines high rate of union with a low complications rate and early return to function. ${ }^{28}$

Interlocking nail is an intramedullary nail that is fixed to the bone with screws at both ends. Close tibial interlocking nail is a procedure in which closed reduction of the fracture is done without opening the fracture site and then intramedullary interlocking nail is introduced at the tibial tuberosity and fixed at the both ends with screws. Close tibial interlock nailing was initially used without reaming but due to delayed union and 
non-union the reamed interlocking was started. It provides the ability to control normal length, correction of angulations and rotation. In interlocking system, sophisticated equipment CARM is sometimes need to locate and drill the distal screw site when difficulties arise and in distal fourth fracture to see the end of the nail.

Objective of the study: To Evaluate Status of Union, Rate of infection, Mal-alignment, Functional Joint Movement.

\section{Material and Methods}

This study was prospective and interventional. This study was carried out in private hospital of Rajshahi over a period of 3 years. Total 35 patients were studied all were male. Inclusion criteria was Displaced closed fracture shaft of the Tibiaand open fracture Gustillo 1,2 and 3A attended within 24 hours. Exclusion criteria were patient below 16 years, Fracture with grossly lacerated, undisplaced fracture, patient unwilling to operate. Most of the cases was operated within one week,

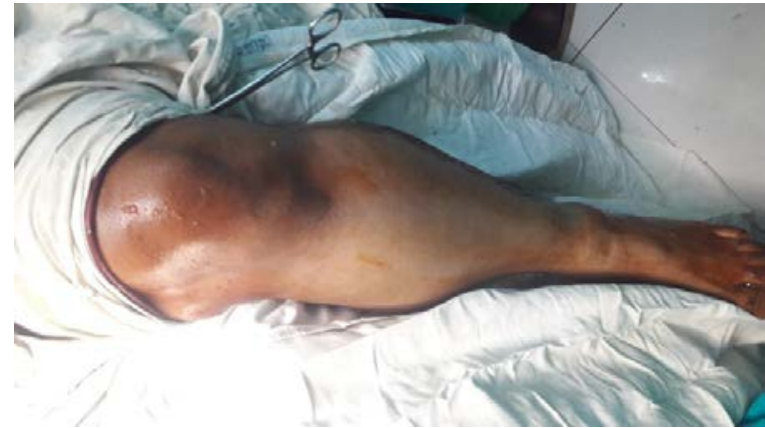

Fig: 1 A. Position of limb

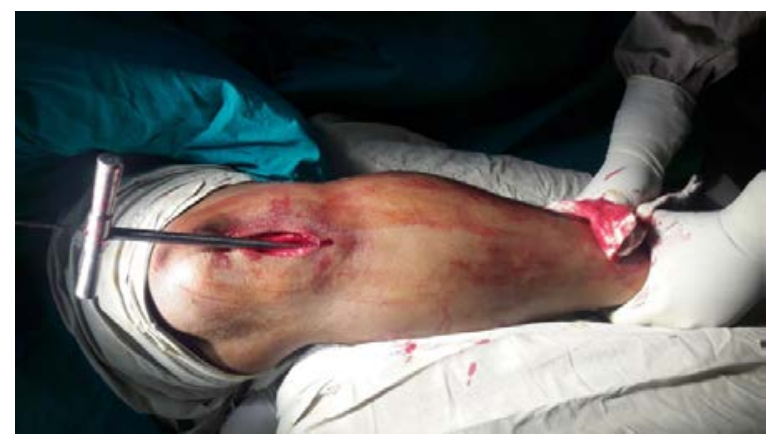

Fig: 1 C. Insertion of reamer only two cases operated at 2 months due angulation following conservative treatment. Open fracture was fixed within 24-48 hours. Motor vehicle Accident was the main cause. Right leg was affected more than left. Mid shaft fracture was more than other part. 29 fractures were closed, 3(Three) fractures were open (Gustillo type-1),one fracture was G-3A, Two patients had impending compartment syndrome with fracture blister. Total operating time was about 60 minutes. Broad spectrum antibiotic injectable Moxifloxacin was used in most of the cases for 2 days followed by oral, Injectable Meropenem was used for the open fracture. The G-3A fracture wound were covered by Hemisoleal flap after primary surgery and postoperative period was uneventful. Most of the cases image intensification was not used only three cases needs image intensification those fracture was in lower $1 / 4$ th to see the End of Nail but for screw insertion C-Arm was not used.

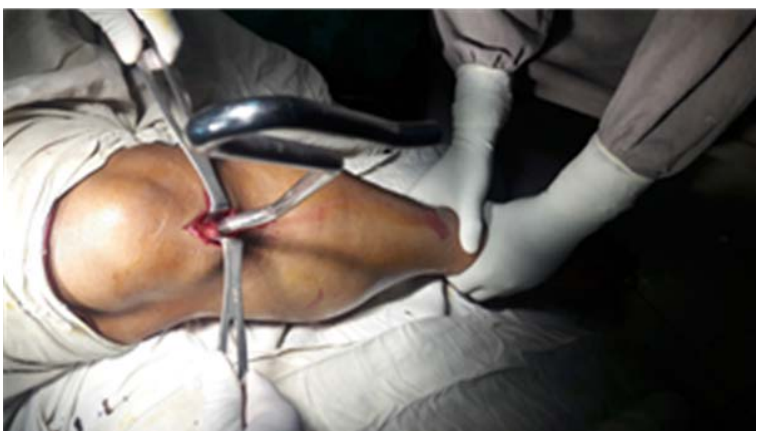

Fig: 1 B. Insertion of awl

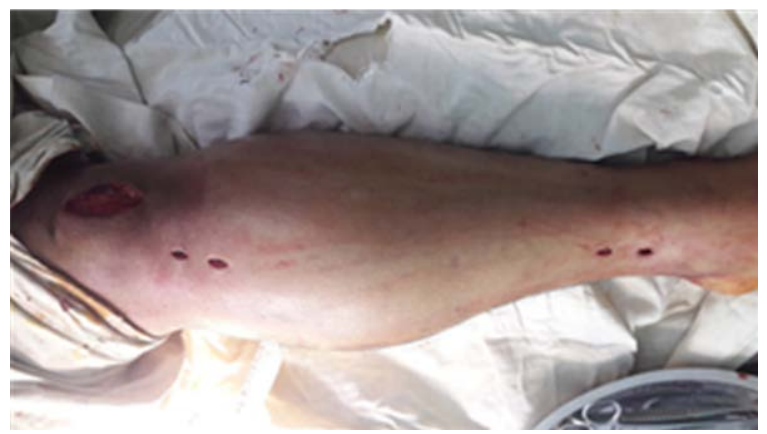

Fig: 1 D. Nail \& screw insertion 
Operative Technique: Under Spinal anesthesia patient was positioned in supine. The fracture limb was hanged on the side of table. The entry site was made using an incision extending from inferior pole of patella to the tibial tuberosity. Patellar tendon was split vertically in the midline to select the entry site. If a transtendinous incision was used it is noted that the guide wire or awl entry should be medialized from the line of this split about 5 to $7 \mathrm{~mm}$ to gain a midline entry site into the tibia. The entry point was about 5 $\mathrm{mm}$ below the articular cartilage just below pad of fat. After insertion of Awl, A rigid cannulated reamer of $8 \mathrm{~mm}$ introduced into the proximal fragment, the knee was flexed more than $90^{\circ}$. One assistant pull the foot down to reduce the fracture site and another assistant will held the knee maintaining flexion. Then the guide wire was passed into the distal fragment, if the guide wire passed properly then grating sensation of the cancellous bone found, and subsequent thud of the guide wire hitting the plafond can be felt.

Further reaming was done gradually by sequential reamer, we used rigid reamer. The canal is overreamed by $1 \mathrm{~mm}$ to allow passage of the nail. Then the nail was inserted maintaining the knee flexion more than $90^{\circ}$. After insertion of the nail limb was kept on the bed in figure of four positions. The screw was inserted with guidance of guide wire. Some times for putting of the distal screw k-wire were used for searching the distal screw hole. All four were screw used and the wound was closed. Sterile dressing was applied without any cast.

\section{Case- 1}

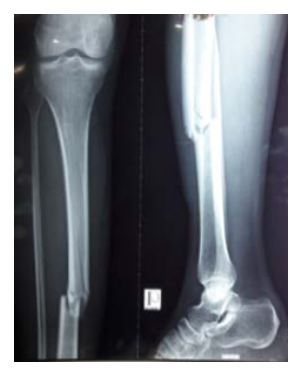

Fig: 2a

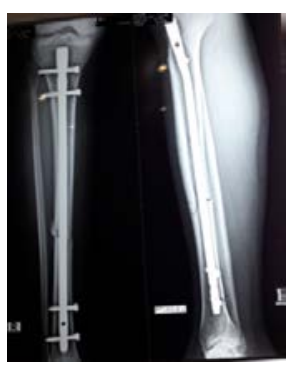

Fig: $2 b$

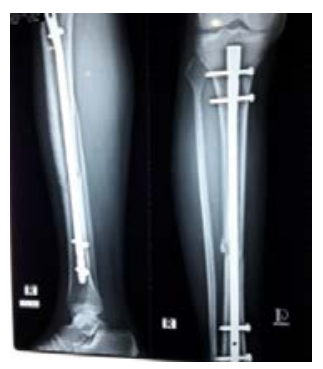

Fig: 2c

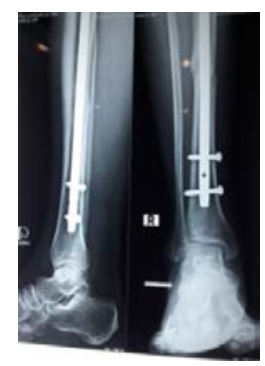

Fig: 2d

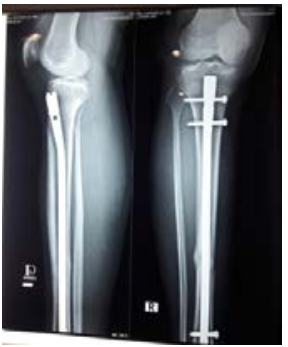

Fig: 2e

a) Preoperative $x$-ray right leg showing fracture tibia, b) post-operative x-ray after closed nailing, c) follow up after 4 weeks, d and e) follow up after 12 weeks.

\section{Case-2}

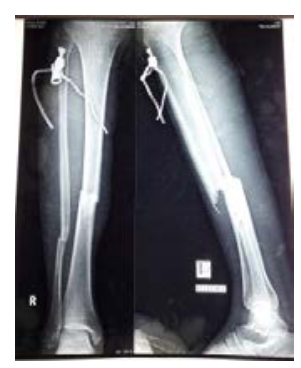

Fig: 3a

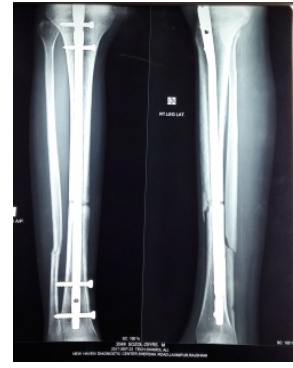

Fig: 3b

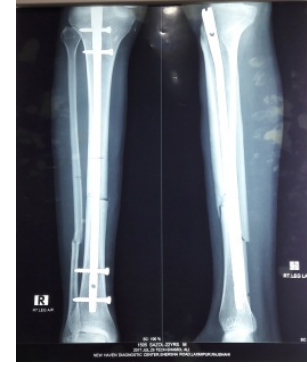

Fig: 3c

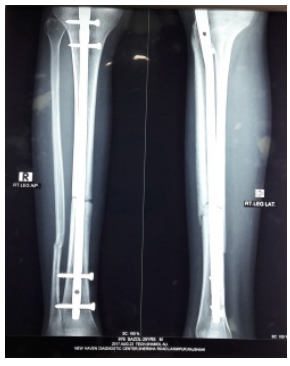

Fig: 3d

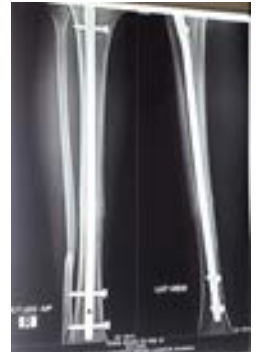

Fig: 3e

a) Preoperative x-ray right leg showing fracture tibia fibula, b) post-operative x-ray after closed nailing, c) follow up after 4 weeks, d) follow up after 8 weeks, e) follow up after 16 weeks. 


\section{Results}

In our study most of the patients aged between 2040 years. Most of the fracture was at the middle third. Closed fracture occupies 83\%. Motor vehicle accident was the principle mode of injury. The mean operating time was about 60 minutes. All the fracture united at mean of 17 weeks.

Table-1: Age distribution of the patients $(n=35)$

\begin{tabular}{|l|l|l|}
\hline Age(years) & Number & Percentage (\%) \\
\hline $20-30$ & 11 & 34 \\
\hline $31-40$ & 08 & 22 \\
\hline $41-50$ & 05 & 14 \\
\hline $51-60$ & 08 & 22 \\
\hline $61-70$ & 03 & 8 \\
\hline
\end{tabular}

Table-2: Site of fracture $(n=35)$

\begin{tabular}{|l|l|l|}
\hline Site of fracture & Number & Percentage (\%) \\
\hline Proximal 1/3rd & 02 & 5.7 \\
\hline Middle 1/3rd & 26 & 74.2 \\
\hline Distal 1/3rd & 06 & 17.14 \\
\hline Segmental & 01 & 2.8 \\
\hline
\end{tabular}

Table-3: Mode of injury ( $\mathrm{n}=35)$

\begin{tabular}{|l|l|l|}
\hline Mode of injury & Number & Percentage (\%) \\
\hline $\begin{array}{l}\text { Motor vehicle } \\
\text { accident }\end{array}$ & 32 & 91 \\
\hline Fall from height & 3 & 09 \\
\hline
\end{tabular}

All the patient have full Range of knee movement. 7(20\%) patients develop knee pain. Excellent results found in 32 cases. Only 3 cases found good result. Superficial infection occurs in 3 (8.5\%) cases. Infection recovers by conservative treatment. No patient develops deep infection. No case of implant failure, malunion or nonunion during the study period. One patient cannot extend toes due to development of post -operative compartment syndrome.
Table-4: Type of fracture $(n=35)$

\begin{tabular}{|l|l|l|}
\hline Type of fracture & Number & $\begin{array}{l}\text { Percentage } \\
(\%)\end{array}$ \\
\hline Close fracture & 29 & 83 \\
\hline Open G-1 & 03 & 08 \\
\hline Open G-3A & 01 & 03 \\
\hline $\begin{array}{l}\text { Impending } \\
\text { compartment } \\
\text { syndrome with Blister } \\
\text { formation. }\end{array}$ & 02 & 06 \\
\hline
\end{tabular}

\section{Discussion}

This study was carried out to evaluate the results of closed reamed Nail for Closed and Open fracture Tibia Gustillo 1, 2, and 3A. Tibial fractures are the most common of the long bone fractures with an annual incidence of two tibial shaft fractures per 1000 individuals. ${ }^{29}$ The choice of treatment depends on fracture location, displacement, comminution, soft tissue condition, and local tradition, but for displaced shaft fractures in the adult, some studies recommend reamed intramedullary nailing as the preferred method. ${ }^{29,30}$

The reamed intramedullary nail provides biomechanical advantages through its central placement, large diameter, and locking screws that secure rotation and length. A small incision for nail entry away from the fracture reduces the risk of infection, and auto transplantation of bone through reaming promotes bone healing. ${ }^{31}$ The procedure has a union rate greater than $95 \%$ for closed fractures in numerous clinical studies. ${ }^{32}$

Larsen et al. ${ }^{33}$ studied 45 patients and concluded that the average time to fracture healing was 16.7 weeks in reamed group and had two malunion. Our study shows union at 17 weeks with no malunion.

Vidyadhara et $\mathrm{al}^{34}$ studied the clinico-radiological outcome of interlock nail in tibia in which he found that the average time of fracture healing was 20.1 weeks while in our study it was 17 weeks. He also pointed out that meticulous intramedullary 
nailing for tibial diaphyseal fracture has excellent clinico-radiological out come and is relatively safe. Court-Brown et al. ${ }^{35,36}$ studied 25 patients with average union time of 15.4 weeks with no infection, malunion, non union or delayed union. Result of healing time of our study similar or better than previous study.

Infection rates are directly proportional to the severity of injury as defined by the GustiloAnderson classification as well as the host comorbidities. ${ }^{37-39}$ Superficial infection usually resolves with minimal intervention; however, deep infection warrants multiple additional surgical procedures and often results in significant morbidity. ${ }^{40}$ Multiple studies reported infection rates following intramedullary nailing of open tibial fractures. Court Brown reported infection rates ranging from $1.8 \%$ to $12.5 \% .{ }^{41}$ Yokoyama et al., Agrawalet al. and Joshi et al. reported deep infection rates of $6.1 \%, 10 \%$ and $10.1 \%$ respectively. ${ }^{42-44}$ The results in this study show a superficial infection rate of $8.5 \%$ and no deep infection and were comparable to international literature.

The current management trend for Gustilo grade 1, 2 , and $3 \mathrm{~A}$ open fractures of the tibia is to perform a reamed or undreamed intramedullary nail ideally within six to eight hours of injury. ${ }^{45}$ However, the traditional 'six hour rule' has been challenged in recent literature. ${ }^{46,47}$ Originally described by Friedrich in 1898, multiple studies have shown that this narrow time window should not be followed rigidly. ${ }^{48,49}$ In our local hospitals, patient usually not attended within 6 hours. The mean time to surgery for Open fracture was 24-48 hours. Although we still advocate surgical debridement and stabilization as soon as possible, this delay was not associated with the development of infection.

Vaisto et $\mathrm{al}^{50}$ studied thirty six patients in whom 12 (33\%) patients were painless at knee and ankle and $24(67 \%)$ patients had anterior knee pain at follow-up while in our study knee pain was observed in $07(20 \%)$ patients.

\section{References}

1. Kulkarni G.S: Text book of Orthopedics and Trauma,Jaypee Brothers, Medical publishers (P.) Ltd 1999, New Delhi.

2. Rhinelander FW. Tibial blood supply in relation to fracture healing.ClinOrthopRelat Res. 1974;105:3481.

3. Whittle AP. Fractures of the lower extremity. In: Canale ST, Beaty JH. Campbell's Operative Orthopaedics 11th ed. Philadelphia; Elsevier; 2008:3086-217

4. Elis $\mathrm{H}$. The speed of healing after fracture of tibial shaft. J Bone J Surg (Br) 1952; 40B ; 42-6.4.

5. Sarmiento A.A functional below-the-knee brace for tibial fractures. J Bone Joint Surg (Am) 1970; 52 : 295-311.

6. Janssen KW, Biert J, van Kampen A. Treatment of distal tibial fractures: Plate versus nail: $A$ retrospective outcome analysis of matched pairs of patients. IntOrthop 2007; 31 : 709-14.

7. Myers SH, Spiegel D, Flynn JM. External fixation of high-energy tibia fractures. J PediatrOrthop 2007; 27 : 537-9.

8. Tornetta P 3rd, Bergman M, Watnik N, Berkowitz G, Steuer J. Treatment of grade III open tibial fractures. A prospective randomized comparison of external fixation and non reamed locked nailing. $\mathrm{J}$ Bone joint Surg 1994; 75 : 13-9.

9. White RR, Babikian GM, Pace A. Tibia, shaft. In: Ruedi TP, Buckley RE, Moran CG. AO Principles of fracture Management. 2nd ed. Switzerland: Thieme; 2007:835-52.

10. Lottes, JO. Closed reduction, plate fixation and medullary nailing of fracture of both bones of the leg.J Bone Joint Surg (A). 1952; 34A : 861.

11. Kyle R.F.Biomechanics of intramedullary nailing fracture fixation.Orthopaedics 1985; 8 : 1356-9.

12. LottesJ.O.Medullary nailing of the tibia with the triflange nail.ClinOrthop 1974; 105 : 253-60.

13. Janssen KW, Biert J, Kampen AV. Treatment of distal tibial fractures: plate versus nail. IntOrthop 2007; 31:709.

14. Whittle AP, Russel TA, Taylor JC. Treatment of openfractures of the tibial shaft with the use of interlocking nailwithout reaming, JBJS (Am) 1992; 74 (8): 1162-71.

15. Kessler SB, KKJ Hallfeldt Et al. Effect of reaming andintramedullary nailing on fracture healing, ChirungischeKlinikInnenstadt and policlinik der LMU, D-8000,Munich Federal Republic of Germany.

16. Ali A, Anjum MP, Humail SM, Qureshi MA. Results of interlocking nail in tibialdiaphyseal fractures. J Pak OrthopAssoc 2009; 21: (2): 36-44 
17. Ryan SP, Pugliano V. Controversies in initial management of openfractures. Scand J Surg. 2013; 103: 132-37.

18. Harley BJ, Beaupre LA, Jones CA, Dulai SK, Weber DW.The effect of timeto definitive treatment on the rate of nonunion and infection in openfractures.J Orthop Trauma. 2002; 16:484-90.

19. Gustilo RB, Merkow RL, Templeman D.The management of openfractures.J Bone Joint Surg Am, 1990;72-A: 299-304.

20. Pollak AN, Jones AL, Castillo RC, Bosse MJ, et al. The relationship between time to surgical debridement and incidence of infection after openhigh-energy lower extremity trauma.J Bone Joint Surg Am. 2010; 92-A:7-15.

21. Clifford R, Lyons $T$, Webb J. Complications of external fixation of openfractures of the tibia. Injury. 1987; 18(3): 174-6.

22. Holbrook JL, Swiontkowski M, Sanders R. Treatment of open fractures ofthe tibial shaft: Ender nailing versus external fixation. A randomized, prospective comparison.J Bone Joint Surg Am. 1989; 71A:1231-38.

23. Finkemeier CG, Schmidt AH, Kyle RF, Templeman DC, et al. A prospective, randomized study of intramedullary nails inserted with and without reamingfor the treatment of open and closed fractures of the tibial shaft. $J$ OrthopTrauma. 2000; 14:187-93.

24. Keating $J$, McQueen $M$. Infection after intramedullary nailing of the tibia.Incidence and protocol for management.J Bone Joint Surg $\mathrm{Br}$. 1992; 74-B:770-74.

25. Obremskey W, Molina C, Collinge C, Nana A, et al. Current practice in the management of open fractures among orthopaedic trauma surgeons. PartA: initial management. A survey of orthopaedictrauma surgeons.J OrthopTrauma. 2014; 28: 198-202.

26. Bhandari $M$, Guyatt $G H$, Tornetta III $P$, Swiontkowski MF, et al. Currentpractice in the intramedullary nailing of tibial shaft fractures: an internationalsurvey. J Trauma. 2002; 53:725-32.

27. Busse JW, Morton E, Lacchetti C, Guyatt GH, Bhandari M. Current management of tibial shaft fractures: a survey of 450 Canadian orthopedictrauma surgeons. Actaorthopaedica. 2008; 79:689-94.

28. Zaman A, Khan AH, Aziz A. Clinical outcome of close intramedullary interlocking nail in fractured tibia. J Pak OrthopAssoc 2008; 20(1): 26-37.

29. Alho A, Benterud JG. Comparison of functional bracing and locked intramedullary nailing in the treatment of displaced tibial shaft fractures. Clin Orthop Relat Res. 1992; 277:243.
30. Karladani AH, Granhed H, Edshage B, Jerre R, Styf J. Displaced tibial shaft fractures: a prospective randomized study of closed intramedullary nailing versus cast treatment in 53 patients. ActaOrthop Scand. 2000;71:160-6.

31. Finkemeier CG, Schmidt AH, Kyle RF. A prospective, randomized study of intramedullary nails inserted with and without reaming for the treatment of open and closed fractures of the tibial shaft. J Orthop Trauma. 2000;14:187.

32. Court-Brown CM. Reamed intramedullary tibial nailing: an overview and analysis of 1106 cases. J Orthop Trauma. 2004; 18:96-101

33. Larsen LB, Madsen JE, Høiness PR, Øvre S. Should insertion of intramedullary nails for tibial fractures be with or without reaming? A prospective, randomized study with 3.8 years' follow-up. J Orthop Trauma 2004 Mar;18(3):144-9.

34. Vidyadhara S. Sharath KR. Prospective study of the clinico-radiological outcome of interlocked nailing in proximal third tibial shaft fractures. Injury 2006; 37 : 536-42.

35. Court-Brown CM, Keating IF, McQueen MM. Infection after intramedullary nailing of the tibia: incidence and protocol for management. J Bone Joint Surg [Br] 1992; 74 : 770-4.

36. Court-Brown CM. Will K Christie J, McQueen MM. Reamed or unreamed nailing for closed tibial fractures. A prospective study in Tscherne C1 fractures. J Bone Joint Surg [Br] 1996; 78 : 580-3

37. Bowen TR, Widmaier JC. Host classification predicts infection after openfracture. ClinOrthopRelat Res. 2005;433:205-11.

38. Gustilo R, Anderson J. Prevention of infection in the treatment of onethousand and twenty-five open fractures of long bones: retrospective andprospective analyses. $\mathrm{J}$ Bone Joint Surg Am. 1976;58:453-58.

39. Patzakis MJ, Wilkins. Factors influencing infection rate in open fracturewounds. ClinOrthopRelat Res. 1989;243:36-40.

40. Patzakis MJ, Zalavras CG. Chronic posttraumatic osteomyelitis andinfected nonunion of the tibia: current management concepts. J Bone JointSurg Am. 2005;13-A:417-27

41. Harrison W, Lewis C, Lavy C. Open fractures of the tibia in HIV positive patients:a prospective controlled single-blind study. Injury.2004;34:852-56.

42. Yokoyama K, Itoman M, Uchino M, Fukushima K, et al. Immediate versusdelayed intramedullary nailing for open fractures of the tibial shaft: a multivariateanalysis of factors affecting deep infection and fracture healing.Indian $\mathrm{J}$ Orthop. 2008;42:410. 
43. Joshi D, Ahmed A, Krishna L, Lal Y. Unreamed interlocking nailing in openfractures of tibia. $J$ Orthop Surg (Hong Kong). 2004; 12:216.

44. Agrawal A, Chauhan VD, Maheshwari RK, Juyal AK. Primary Nailing in theOpen Fractures of the Tibia-Is it worth? J ClinDiagn Res. 2013; 7:1125.

45. Okike $\mathrm{K}$, Bhattacharyya $\mathrm{T}$. Trends in the management of open fractures: acritical analysis. $J$ Bone Joint Surg Am. 2006; 88-A:2739-48.

46. Kamat AS. Infection rates in open fractures of the tibia: is the 6-hour rulefact or fiction? AdvOrthop. 2011

47. Pollak AN, Jones AL, Castillo RC, Bosse MJ, et al. The relationship between time to surgical debridement and incidence of infection after openhigh-energy lower extremity trauma.J Bone Joint Surg Am. 2010; 92-A:7-15.
48. Singh J, Rambani R, Hashim Z, Raman R, Sharma $H K$. The relationship between time to surgical debridement and incidence of infection in gradelll open fractures.Srategies Trauma Limb Reconstr. 2012;7:33-37.

49. Bali K, Aggarwal S, Kumar V, Mootha AK, et al. Operative management oftype II and type IIlaopen tibial fractures presenting from 6-24 hours afterinjury: an Indian experience. CurrOrthop Pr. 2011; 22:262-66.

50. Vaisto 0, Toivanen J. Paakkala T. Jarvela T, Kannus $P$, Jarvinen $M$. Anterior knee pain after intramedullary nailing of a tibial shaft ftacture; An ultrasound study of the patellar tendons of 36 patients. Orthop Trauma 2005; 19: 311-6. 